\title{
PENYUSUTAN SEBAGAI SALAH SATU FUNGSI MANAJEMEN ARSIP DI BALAI DIKLAT KEAGAMAAN SEMARANG
}

\author{
Riskha Nur Fitriyah \\ Balai Diklat Keagamaan Semarang \\ riskhafitriyah@gmail.com
}

\begin{abstract}
Abstrak - Penyusutan Sebagai Salah Satu Fungsi Manajemen Arsip di Balai Diklat Keagamaan Semarang. Penyusutan arsip dalam suatu organisasi atau instansi harus dilakukan untuk mengurangi arsip in aktif yang tidak memiliki nilai guna arsip. Terdapat tiga fungsi manajemen arsip dalam organisasi atau instansi, yaitu fungsi penciptaan, fungsi penggunaan serta fungsi pemeliharaan dan penyusutan. Penelitian ini dilakukan untuk mendeskripsikan proses penyusutan arsip in aktif dan mengidentifikasi kendala yang dihadapi pada Bagian Tata Usaha di Balai Diklat Keagamaan Semarang. Metode penelitian yang digunakan adalah kualitatif, dimana peneliti ikut terlibat secara langsung sebagai instrumen penelitian. Dalam penelitian ini, metode yang digunakan yaitu kualitatif. Salah satu ciri dari metode kualitatif adalah peneliti ikut terlibat secara langsung sebagai instrumen penelitian. Observasi, wawancara dan dokumentasi merupakan teknik pengumpulan data yang dilakukan. Dari hasil penelitian yang telah dilakukan didapatkan bahwa kegiatan penyusutan arsip dilakukan di Unit Kearsipan (Bagian Tata Usaha) dengan 3 tahapan, yaitu pemindahan arsip, pemyerahan dan pemusnahan. Adapun kendala yang dihadapi adalah minimnya sarana dan prasarana, kurangnya dukungan dari Pimpinan dan kurangnya kemampuan SDM.
\end{abstract}

Kata kunci : penyusutan, manajemen arsip dan arsip in aktif

\begin{abstract}
Depreciation as One of the Functions of Archive Management in Semarang Religious Training Center. Depreciation of records in within an organization should be undertaken to reduce inactive records that have no archival value. Three archive management functions within the organization consist of creation, use, maintenance and depreciation. This study aims to determine the process depreciation of inactive records and obstacles encountered in the implementation of records management in institutions of Religious Training Semarang. The method of the research is case study with descriptive qualitative. The research showed the result that depreciation of record activities in the Unit Archives (Administrative Section) with 3 stages, are removal of records, submission and disposal of archives. The obstacles encountered are inadequate of facilities and infrastructure, lack of leadership support and lack of human resources capability.
\end{abstract}

Keyword: Depreciation, archive management and the records is active

\section{PENDAHULUAN}

Pengertian arsip secara umum yaitu rangkaian kegiatan maupun peristiwa yang tersimpan dalam beragam bentuk dan media sesuai dengan perkembangan teknologi, informasi dan komunikasi. Pada umumnya, arsip diciptakan atau dibuat serta diterima oleh semua organisasi maupun instansi seperti lembaga negara, pemerintah daerah, lembaga pendidikan, perusahaan, organisasi politik, organisasi kemasyarakatan dan perseorangan dengan pelaksanaan kehidupan bermasyarakat, berbangsa dan bernegara (KMA, 2010). Arsip juga dapat diartikan sebagai informasi yang terekam mengenai segala sesuatu tentang pelaksanaan fungsi dan tugas pokok 
sebuah organisasi ataupun instansi. Sumber informasi faktual dan objektif yang tentang berbagai bidang program dan kegiatan yang telah dilaksanakan oleh suatu organisasi juga merupakan salah satu arti dari arsip. Fungsi arsip bagi suatu organisasi maupun instansi terbagi menjadi arsip dinamis dan arsip statis. Arsip dinamis adalah sumber informasi manajemen yang sah dalam mendukung setiap administrasi yang akuntabel dan transparan. Tahap penciptaan, tahap penggunaan, tahap pemeliharaan dan tahap penyusutan arsip merupakan empat instrumen pokok dalam pengelolaan arsip yang berfungsi sebagai pengontrol dalam setiap praktik kearsipan (Azmi, 2016).

Aset suatu lembaga maupun instansi yaitu terselenggaranya praktik kearsipan secara baik dan benar. Selain itu, arsip juga dapat bermanfaat untuk bahan pengambilan keputusan secara cepat dan tepat. Berdasarkan fungsi dan kegunaannya, arsip dibedakan menjadi dua. Pertama yaitu arsip dinamis dan kedua arsip statis. Arsip yang masih digunakan secara langsung dalam kegiatan penciptaan arsip dan disimpan dalam jangka waktu tertentu dinamakan arsip dinamis. Arsip dinamis terbagi menjadi dua, yakni arsip aktif dan arsip inaktif. Arsip aktif yaitu arsip dinamis yang masih digunakan oleh pengguna arsip secara terus menerus, sedangkan arsip inaktif diartikan sebagai arsip dinamis yang frekuensi penggunaan dalam praktik kearsipan telah mengalami penurunan. Sedangkan arsip yang dihasilkan oleh pencipta arsip dengan nilai guna kesejarahan yang telah habis masa retensinya serta berketerangan permanen, yang kemudian diverifikasi oleh ANRI atau lembaga kearsipan di daerah dinamakan arsip statis (Rachmaji, 2016).

Dalam KMA No. 44 Tahun 2010, diterangkan bahwa terdapat lima siklus kehidupan arsip yang dimulai dari tahap penciptaan, tahap penggunaan, tahap penyimpanan dan penemuan kembali, tahap pemeliharaan serta tahap penyusutan. Tahap penyusutan dapat dilakukan dengan cara pemindahan arsip, pemusnahan arsip dan pelestarian arsip yang permanen (penyerahan kepada lembaga arsip). Adapun tujuan utama dilakukan proses penyusutan arsip yaitu untuk mengendalikan arus akumulasi penambahan arsip di sebuah organisasi, lembaga maupun instansi yang cukup tinggi. Proses penyusutan arsip juga dapat menjamin keselamatan arsip pada arsip yang bernilai permanen dalam retensinya sebagai bukti pertanggung jawaban secara nasional (KMA, 2010).

Tumpukan akumulasi arsip, baik arsip aktif maupun in aktif di sebuah organisasi, lembaga maupun instansi menjadi gambaran nyata betapa pentingnya peran seorang pengelola arsip maupun arsiparis yang memiliki ketekunan, kemauan, ketrampilan, ketelitian, kompetensi serta profesional dalam menangani arsip. Padatnya kegiatan diklat di BDK Semarang menyebabkan arsip, baik aktif maupun in aktif tercipta dalam jumlah yang cukup banyak setiap tahunnya. Pertambahan volume 
arsip yang banyak dari tahun ke tahun mengakibatkan kurangnya efisien dalam penyimpanan arsip bahkan seringkali terjadi kondisi arsip kacau yang tidak tertata. Jika kondisinya sudah seperti ini, harus dilakukan proses penyusutan arsip. Hasil observasi di ruang arsip inaktif pada Bagian Tata Usaha, ditemukan adanya penumpukan arsip inaktif yang tidak dikelola dengan baik, belum dilakukan penilaian dan penyusutan arsip. Arsip terlihat masih tercampur antara arsip sebagai bahan buktiotentik yang bersifat permanen, arsip yang harus musnah serta non arsip. Dengan kondisi arsip yang demikian, maka sangat sulit untuk melakukan penemuan kembali arsip yang dibutuhkan.

Undang - Undang No. 43 Tahun 2009 tentang kearsipan menekankan bahwa praktik kearsipan di suatu lembaga, organisasi maupun instansi harus menjamin perlindungan dan penyelamatan arsip melalui tindakan manajemen arsip secara tertib, mengingat pentingnya arsip sebagai sumber informasi dan pusat ingatan (UU No. 49, 2009). Dari uraian di atas, penulis tertarik untuk meneliti tentang penyusutan arsip sebagai salah satu fungsi dalam manajemen kearsipan. Adapun tujuan dari penelitian ini adalah untuk mendeskripsikan proses penyusutan arsip in aktif dan mengidentifikasi kendala yang dihadapi pada Bagian TU sebagai Unit Kearsipan dalam melakukan kegiatan penyusutan arsip agar tercipta arsip yang tertata rapi sehingga memudahkan dalam penemuan kembali, baik untuk arsip aktif, arsip inaktif maupun arsip statis.

Manajemen dapat diartikan sebagai suatu proses untuk mencapai tujuan tertentu dengan cara memanfaatkan sumber daya organisasi melalui fungsi perencanaan (planning), fungsi pengorganisasian (organizing), fungsi penggerakan (actuating) dan fungsi pengendalian (controlling). Dalam hal ini arsip menjadi salah satu sumber daya yang sangat penting bagi suatu organisasi, lembaga maupun instansi. Informasi yang cepat, akurat dan lengkap serta digunakan sebagai bahan pengambilan keputusan yang baik dan benar merupakan salah satu kegunaan arsip. Untuk itulah manajemen arsip di suatu organisasi, lembaga maupun instansi sangat diperlukan. Manajemen arsip harus dilaksanakan dengan memperhatikan prinsip - prinsip kearsipan untuk mencapai tujuan yang diharapkan (Sutirman, 2019). Pelaksanaan fungsi manajemen dalam mengelola keutuhan daur hidup (life cycle) arsip disebut dengan manajemen arsip. Daur hidup (life cycle) arsip dimulai dari tahap penciptaan, tahap penggunaan, tahap pemeliharaan dan tahap penyusutan arsip (Arsip Nasional Republik Indonesia, 1999).

Tahap penciptaan arsip (record creation) meliputi proses penulisan/pembuatan surat, memo, petunjuk, laporan, print out dari komputer/laptop, film, rekaman dan lain sebagainya yang kemudian disampaikan kepada orang lain dalam suatu instansi maupun kepada pihak eksternal di luar instansi. Berikutnya yaitu tahap penggunaan arsip, arsip digunakan dalam pelaksanaan praktik kearsipan, dasar pengambilan keputusan, peran manajerial, sebagai alat pembuktian, bahan 
pertimbangan, sebagai referensi dan keperluan legal tertentu. Selanjutnya tahap pemeliharaan arsip, pada tahap ini setelah arsip digunakan kemudian disimpan dan dapat digunakan kembali saat dibutuhkan. Pemeliharaan arsip dilakukan dengan cara dijaga kebersihannya, keamanannya serta diberi pestisida agar tidak rusak. Arsip disimpan menurut klasifikasinya baik sebagai arsip aktif, arsip inaktif, bersifat permanen maupun sementara sesuai jangka waktu penyimpanannya. Arsip juga dapat disimpan dalam filling cabinet, folder (map) dan rak arsip. Jangka waktu penyimpanan arsip ditentukan dalam jadwal retensi arsip, apabila arsip telah habis sesuai masa retensinya dilakukan pemindahan arsip. Sedangkan arsip yang tidak memiliki nilai guna dilakukan pemusnahan melalui penghancuran, peleburan atau pembuangan sesuai prosedur yang berlaku (Suraja, 2006).

Sesuai dengan UU No. 49 Tahun 2009, dijabarkan tentang proses penyusutan arsip yang dimulai dengan kegiatan pemindahan arsip in aktif dari unit pengolah ke unit kearsipan. Selanjutnya dilakukan pemusnahan arsip untuk arsip yang telah habis masa retensinya dan tidak memiliki nilai guna. Pelaksanaan proses pemusnahan arsip harus sesuai dengan ketentuan peraturan perundang - undangan. Kegiatan proses penyusutan arsip yang terakhir adalah dengan melakukan penyerahan arsip statis oleh instansi pencipta arsip kepada lembaga kearsipan.

Salah satu cara yang dapat dilakukan untuk mengurangi banyaknya jumlah arsip yang tercipta dalam suatu organisasi, lembaga maupun instansi adalah dengan pemyusutan arsip. Penilaian arsip dengan pemilahan mana arsip yang dapat dipindahkan, dimusnahkan atau diserahkan sesuai dalam jadwal retensi arsip adalah langkah pertama dalam proses penyusutan arsip, kegiatan ini dapat berjalan dengan lancar apabila dilakukan sesuai dengan prosedur yang baik, benar dan dukungan fasilitas yang cukup. Proses penyusutan arsip dilakukan untuk penghematan dan efisiensi tempat serta waktu, pendayagunaan arsip yang maksimal, pengawasan arsip yang bernilai guna tinggi, penyelamatan bahan bukti organisasiterutama untuk arsip statis serta memenuhi persyaratan hukum dan perundangan yang berlaku (Sudjono, dkk, 2007).

\section{METODE}

Penelitian dilakukan dengan menggunakan metode kualitatif, dimana dalam penelitian menekankan pada kedalaman hasil dan peneliti terlibat secara langsung sebagai instrumen penelitian. Metode kualitatif dapat dikatan sebagai suatu penelitian kontekstual yang menjadikan manusia sebagai instrumen, serta disesuaikan dengan situasi yang wajar dalam kaitannya dengan pengumpulan data yang bersifat kualitatif. Observasi, wawancara dan dokumentasi merupakan teknik pengumpulan data yang dilakukan dalam penelitian ini. Metode kualitatif membenarkan 
peneliti untuk dapat mengambil kesimpulan dari penelitian berdasarkan informasi dari informan. Informan ditentukan secara purposive, yaitu teknik pengambilan sumber data dengan pertimbangan tertentu (Creswell, 2010).

Dalam penelitian ini, pemilihan informan dilakukan dengan pertimbangan: (1) memiliki kompetensi untuk memberikan informasi mengenai proses pemindahan, penyusutan dan penyerahan arsip, (2) terlibat dalam kegiatan pemindahan, penyusutan dan penyerahan arsip. Informan ditentukan sejumlah 6 orang yang memenuhi persyaratan. Pengamatan langsung dilakukan pada saat proses penilaian, pemindahan, pemusnahan sampai penyerahan. Penelitian dilakukan selama 3 bulan. Uji keabsahan data dilakukan dengan triangulasi, peneliti melakukan pengecekan serta membandingkan data yang terima dari hasil pengamatan langsung, wawancara dan hasil dokumentasi.

\section{HASIL DAN PEMBAHASAN}

\section{A. Proses Penyusutan Arsip di Balai Diklat Keagamaan (BDK) Semarang}

Balai Diklat Keagamaan Semarang merupakan Unit Pelaksanan Teknis yang bertanggungjawab kepada Kepala Badan Penelitian dan Pengembangan serta Pendidikan dan Pelatihan (Badan Litbang dan Diklat) Kementerian Agama. Balai Diklat Keagamaan Semarang mempunyai tugas menyelenggarakan pendidikan dan pelatihan tenaga administrasi, tenaga teknis dan tenaga keagamaan di lingkungan Kementerian Agama. Dalam melaksanakan tugasnya, Balai Diklat Keagamaan Semarang menyelenggarakan fungsi (1) penyusunan rencana dan program diklat, (2) penyelenggaraan diklat, (3) pelaksanaan evaluasi dan pelaporan hasil diklat serta pelaksanaan urusan administrasi dan rumah tangga. BDK Semarang juga menyelenggarakan jenis Diklat Pengelola Arsip, oleh karena itu ruang arsip pada Bagian TU otomatis menjadi laboratorium arsip saat diklat berlangsung. Arsip yang masih menumpuk dan kacau harus segera di lakukan penilaian, pemililahan serta penyusutan arsip.

Penyusutan arsip merupakan salah satu peranan penting untuk mengatasi masalah bertumpuknya/bertimbunannya arsip yang tidak memiliki nilai guna lagi. Arsip-arsip yang tidak berguna itu harus di pilah - pilah untuk dapat dipindahkan, dimusnahkan maupun diserahkan untuk memberi kemungkinan bagi tersedianya tempat penyimpanan dan pemeliharaan yang lebih baik terhadap arsip-arsip yang mempunyai nilai guna. Proses kegiatan penyusutan arsip pada Bagian Tata Usaha sebagai Unit Kearsipan di Balai Diklat Keagamaan Semarang dilakukan sesuai dengan Jadwal Retensi Arsip yang sesuai dengan KMA RI No. 120 Tahun 2013 tentang jadwal retensi arsip fasilitatif dan substantif di lingkungan Kementerian Agama. Dalam Jadwal 
Retensi Arsip ini, memuat unsur-unsur, judul subjek utama yang merupakan gambaran dari seri arsip, jangka simpan arsip, dan nasib akhir dari suatu arsip apakah disimpan permanen atau dimusnahkan. Jika arsip tersebut termasuk arsip statis ataupun arsip yang bernilai permanen maka arsip tersebut akan diserahkan ke badan arsip.

Penyusutan arsip yang dimaksud di lingkungan Balai Diklat Keagamaan Semarang adalah kegiatan untuk mengurangi arsip. Proses penyusutan arsip dimulai dari (1) kegitan pemindahan arsip inaktif dari setiap unit pengolah (Seksi Tenaga Teknis, Seksi Tenaga Administrasi dan Keuangan) ke bagian Tata Usaha sebagai Unit Kearsipan, (2) kegiatan pemusnahan arsip dinamis inaktif dan (3) kegiatan penyerahan arsip dilakukan oleh BDK Semarang kepada Arsip dan Perpustakaan Provinsi Jawa Tengah.

1. Proses Pemindahan Arsip In aktif

Prosedur pemindahan arsip yang berstatus inaktif diperlukan untuk memindahkan arsip inaktif dari sentral file yang terdapat di unit kerja ke pusat arsip atau record center. Agar pemindahan arsip tidak mengalami kendala sebaiknya dilakukan dengan pemilahan, pemeriksaan dan penilaian. Kegiatan pemilahan, pemeriksaan dan penilaian dilaksanakan untuk mengetahui apakah arsip-arsip sudah benar inaktif atau belum. Sedangkan penentuan arsip inaktif berdasarkan jadwal retensi arsip dan dilakukan dengan melihat kolom retensi aktif di dalam jadwal retensi arsip. Setelah diperiksa dan ditentukan sebagai arsip inaktif maka arsiparsip tersebut harus didaftar secara lengkap, baik judul serinya atau jenis arsipnya, tahun, volume, kondisi, penataan, sistem penyimpanan yang digunakan. Penataan arsip inaktif dilakukan sesuai dengan daftar yang telah disusun, hal ini dilakukan untuk menjaga agar penataan dilakukan sebagaimana penataan aslinya (Sanora, 2016).

Pemindahan arsip di BDK Semarang adalah kegiatan fisik memindahkan arsip inaktif dari unit pengolah ke unit kearsipan yang telah dirancang dalam periode waktu yang telah ditentukan dalam KMA RI No. 120 Tahun 2013 tentang Jadwal Retensi Arsip (JRA). Pemindahan arsip inaktif dilaksanakan melalui kegiatan: (1) penyeleksian arsip inaktif, (2) pembuatan daftar arsip inaktif yang akan dipindahkan dan penataan arsip inaktif yang akan dipindahkan dan (3) pembuatan berita acara pemindahan arsip in aktif dari unit pengolah (Seksi TT, seksi TA dan keuangan). 


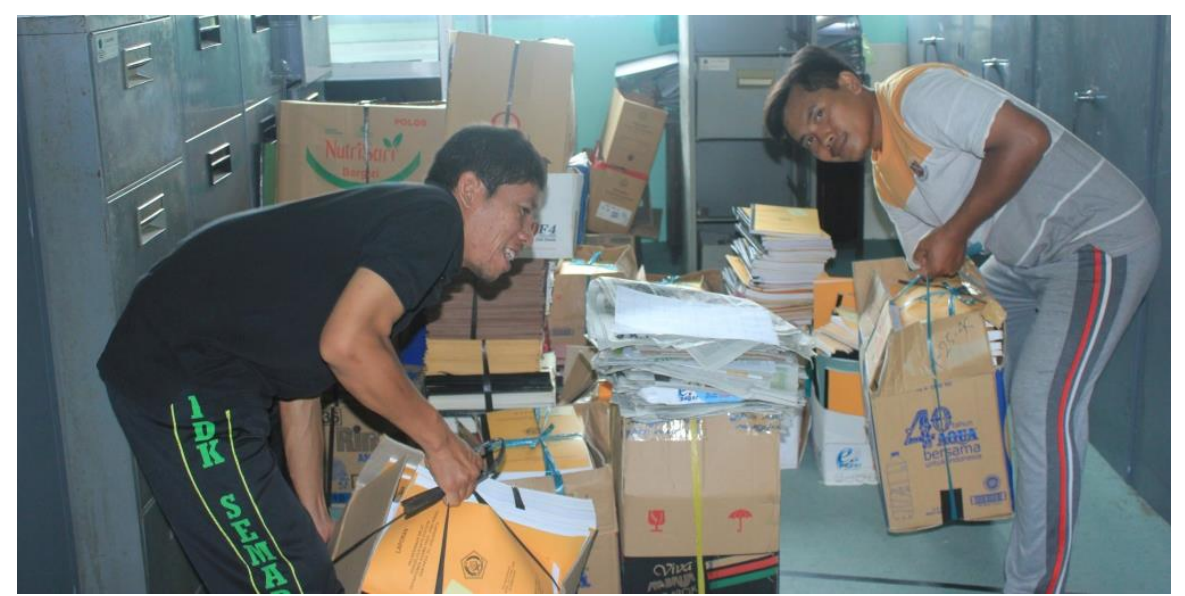

Gambar 1. Pemindahan Arsip in aktif

2. Proses Penataan Arsip in aktif di record center

Arsip in aktif dari ketiga unit pengolah, yaitu seksi TA, seksi TT, dan ruang keuangan terkumpul dalam sebuah ruangan di Unit Kearsipan/bagian Tata Usaha yang dinamakan record center. Record center merupakan pusat arsip sebagai sarana penyimpanan arsip inaktif. BDK Semarang memiliki ruangan sebagai record center di lantai 2 bagian Tata Usaha bersebelahan dengan ruang server. Di dalam record center semua arsip in aktif di tata dan dipilih berdasarkan nilai guna sesuai JRA. Arsip in aktif yang masih dalam masa simpan dan permanen dimasukkan ke dalam boks arsip selanjutnya disusun dalam rak arsip. Semua daftar arsip in aktif dicatat berdasarkan fungsi dan kegunaannya, setiap boks arsip diberi label dan nomor urut daftar arsip in aktif. Arsip in aktif yang sudah tidak memiliki nilai guna di catat dalam daftar arsip musnah.

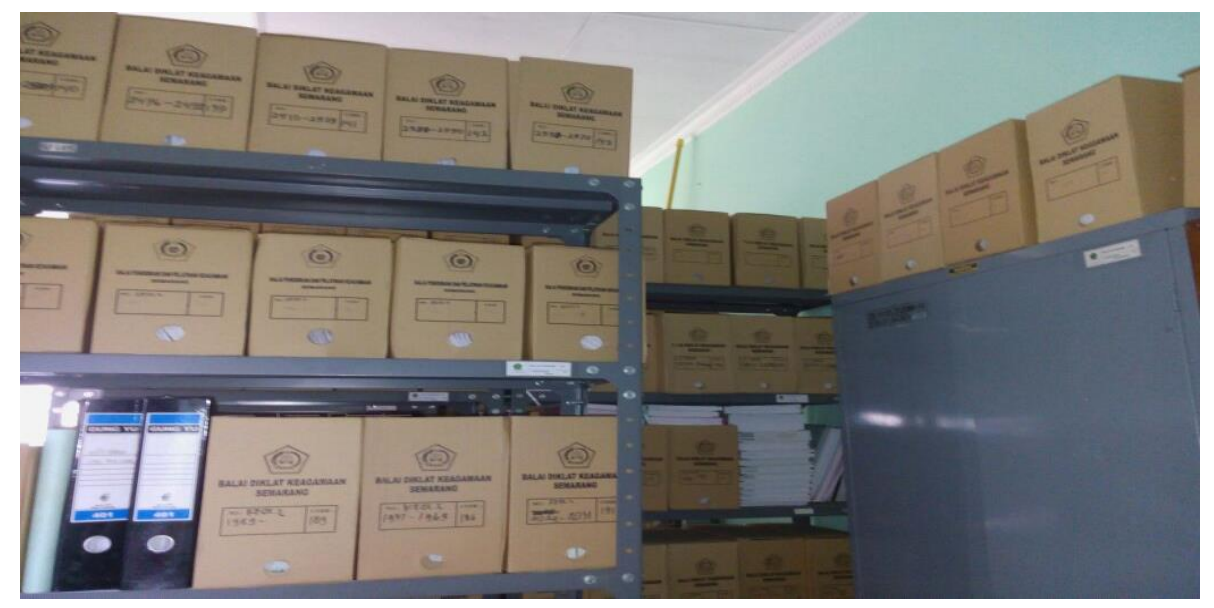

Gambar 2. Ruang record center BDK Semarang 


\section{Penyerahan Arsip}

Penyerahan arsip merupakan tindakan eksternal yang dilakukan dari instansi kepada Arsip Nasional atau badan arsip daerah. Dokumen instansi yang wajib diserahkan kepada Arsip Nasional atau badan arsip daerah yaitu dokumen instansi yang memiliki nilai histories yang penggunaanya berkaitan dengan kegiatan pemerintahan, kegiatan pembangunan nasional, kehidupan kebangsaan yang sering disebut sebagai arsip statis (Ayu \& Windarti, 2013). Kegiatan penyusutan arsip yang dilakukan di BDK Semarang berdasarkan ketentuan KMA RI No. 120 Tahun 2013 tentang Jadwal Retensi Arsip (JRA). Bagi arsip dengan keterangan "PERMANEN atau DINILAI KEMBALI" dalam JRA dapat dilakukan penyerahan di Badan Arsip. Penyerahan arsip in aktif ke Badan Arsip dan Perpustakaan Prov. Jawa Tengah sudah dilakukan BDK Semarang pada Tahun 2014 sebanyak 173 boks arsip dengan Berita Acara (BA) Penyerahan yang ditanda tangani oleh Kepala BDK Semarang dan Kepala Badan Arsip dan Perpustakaan Provinsi Jawa Tengah .

4. Pemusnahan Arsip

Proses pemusnahan arsip dilakukan untuk arsip yang tidak memiliki nilai guna lagi. Proses penyusutan arsip dapat dilakukan dengan cara sebagai berikut: (1) arsip yang akan dimusnahkan dibuatkan daftar arsipnya, yang berisi jenis arsip, jumlah arsip, dan keterangan isi arsip dapat diketik dalam bentuk word atau excel; (2) melakukan pembentukan panitia pemusnahan arsip, panitia pemusnahan arsip terdiri dari arsiparis, pengelola arsip, dan unit hukum; (3) pembuatan surat persetujuan pemusnahan arsip yang di tandatangani pejabat terkait. Apabila pemusnahan arsip sudah disetujui maka dibuatlah berita acara pemusnahan arsip sesuai dengan format yang sudah ditentukan, (4) Eksekusi, pemusnahan dilakukan dengan cara membakar arsip yang akan dimusnahkan dengan disaksikan oleh kepala dinas, kepala unit kearsipan dan satu orang pihak dari biro hukum. Pada saat pemusnahan arsip dilakukan, panitia akan melakukan dokumentasi sebagai barang bukti bahwa pemusnahan arsip telah dilakukan (Fitri dan Marlini, 2013) .

Pemusnahan arsip di BDK Semarang dilakukan dengan penilaian dan pemeriksaan di record center. Untuk arsip yang sudah tidak memiliki nilai guna, telah habis masa penyimpanannya dan di JRA dengan keterangan "MUSNAH" dapat dipisahkan menjadi arsip yang akan dimusnahkan dengan mencatat dalam daftar arsip musnah. Pemusnahan arsip pernah dilakukan pada tahun 2013 sesuai dengan ketentuan dan prosedur dalam KMA No. 44 tahun 2010 tentang Pedoman Penilaian Kearsipan di lingkungan Kementerian Agama. Pemusnahan arsip dilakukan di PT. Barutama Kudus dengan dicacah menjadi bubur kertas. Segala bentuk 
kegiatan penyusutan arsip dilakukan sesuai dengan jadwal retensi arsip. Dengan kata lain instrumen dalam melakukan penyusutan juga sesuai dengan jadwal retensi arsip yang berlaku.

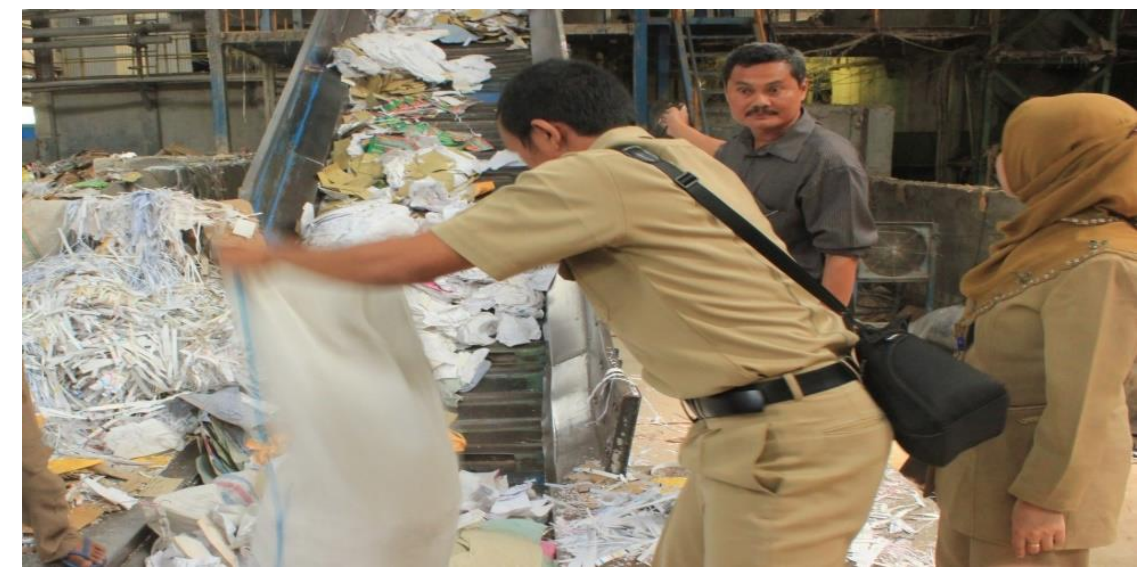

Gambar 3. Proses pemusnahan arsip di PT. Barutama Kudus

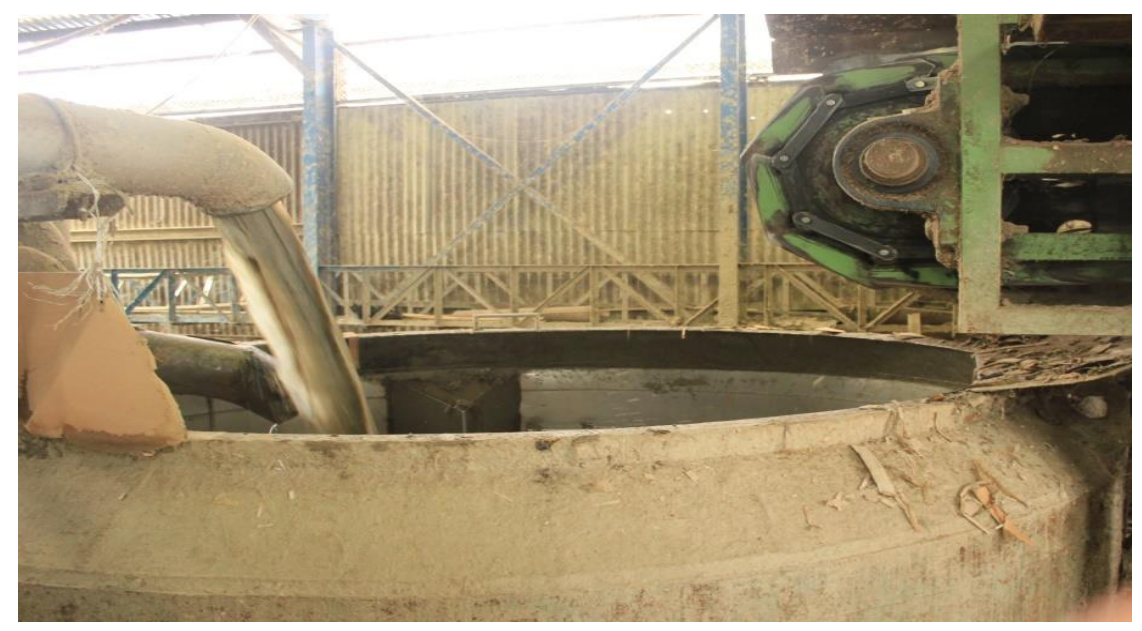

Gambar 4. Proses peleburan arsip yang telah dimusnahkan

\section{B. Kendala Dalam Proses Penyusutan Arsip}

Beberapa kendala yang ditemukan selama proses penyusutan arsip di BDK Semarang antara lain:

1. Kurangnya Sumber Daya Manusia (SDM) dalam bidang kearsipan

Ketiadaan petugas kearsipan yang memiliki latar belakang pendidikan kearsipan merupakan kendala terbesar yang dialami oleh BDK Semarang. BDK Semarang tidak mempunyai pegawai khusus yang fokus mengurus pengelolaan arsip. Selama ini BDK Semarang memperdayakan pegawai dari sub bagian tata usaha yang belum memiliki ketrampilan khusus maupun latar pendidikan yang sesuai mengenai pengelolaan 
arsip untuk mengurus pengelolaan arsip. Secara teori, hal tersebut dapat mengganggu proses pengelolaan arsip, karena pengelolaan arsip tidak dikerjakan oleh orang yang memiliki pengetahuan tentang cara pengelolaan arsip. Pengelola arsip hanya bekerja sesuai dengan apa yang sudah menjadi kebiasaan sebelumnya, bukan atas dasar pengetahuan kearsipan. Petugas yang mengelola arsip hanya mendapatkan informasi dari beberapa kegiatan Orientasi Persuratan dan Kearsipan dari Badan Litbang dan Diklat Kementerian Agama, Diklat Pengelola Arsip serta hasil studi banding ke kantor Arsip dan Perpustakaan Provinsi Jawa Tengah.

Pegawai yang menangani persuratan ada 2 orang, dan 1 orang yang diperbantukan untuk mengelola arsip sehingga sulit melakukan kegiatan penyusutan yang membutuhkan keahlian seorang arsiparis atau tenaga yang ahli di bidang kearsipan. Dengan keadaan kurangnya tenaga, sulit melakukan penyusutan arsip dengan tenaga yang hanya sedikit, sementara hal yang akan dikerjakan tidak sedikit.

2. Kurangnya Perhatian dari Pejabat Terkait

Beban pekerjaan yang cukup banyak dari Kepala maupun Kasubbag TU BDK Semarang, kadang berakibat kurangnya perhatian terhadap penataan dan kondisi arsip. Peralatan dan perlengkapan yang dibutuhkan untuk menyusutkan arsip sering kurang terpenuhi, seperti boks arsip, masker, penyedot debu, sarung tangan, dan ruang khusus untuk memusnahkan arsip atau penyimpan arsip usul musnah kepada pihak ketiga.

3. Ruangan untuk record center terlalu kecil

Ruang pusat arsip BDK Semarang ada di ruang Tata usaha lantai 2 Gedung Kantor dengan luas kurang dari yang dipersyaratkan, tanpa AC dan berdebu. Penerangan dibuat minim untuk menghindari ada jamur yang berkembang karena intensitas cahaya yang agak tinggi. Untuk arsip keuangan dari awal berdirinya BDK Semarang di Tahun 1986 sampai sekarang belum pernah ada penyusutan, karena belum dapat persetujuan dari pihak keuangan, padahal sesuai dengan KMA RI No. 120 Tahun 2013 tentang Jadwal Retensi Arsip (JRA) ada beberapa dokumen yang dapat dimusnahkan. Sehingga dari tahun ke tahun arsip keuangan semakin bertambah banyak dan menumpuk sedangkan ruangan penyimpanan arsip di record center sangat kecil dan sangat terbatas. 


\section{KESIMPULAN}

Tahap penyusutan arsip di BDK Semarang sesuai dengan prosedur perundang - undangan yang berlaku di lingkungan Kementerian Agama. Kegiatan penyusutan arsip meliputi kegiatan: a) Pemindahan arsip ke record center. Pemindahan ini dilakukan dari unit pengolah ke unit kearsipan sebagai record center. Arsip yang dipindahkan merupakan arsip inaktif dari seksi TA, seksi TT dan keuangan.; b) Penyerahan ke Arpus Prov. Jawa Tengah. Arsip yang diserahkan adalah arsip yang sesuai JRA mempunyai keterangan "PERMANEN atau DINILAI KEMBALI" yang mempunyai nilai arsip yang abadi, artinya arsip tersebut disimpan untuk selamanya; c). Pemusnahan adalah kegiatan menghancurkan arsip inaktif yang sudah masuk masa retensi dan tidak lagi digunakan secara fisik dan informasinya. Metode pemusnahan yang dilakukan dengan cara pencacahan dan pembuburan yang dilakukan oleh pihak ketiga yaitu PT. Barutama Kudus.

Kendala terbesar yang dihadapi dalam proses penyusutan arsip adalah kurang SDM atau tenaga di bidang kearsipan. Namun kendala bisa diatasi dengan memohon bantuan bimbingan arsiparis dari Badan Arpus Prov. Jawa Tengah. Dukungan pejabat terkait perihal penataan arsip sebaiknya terus menerus dilakukan agar dapat tercipta kinerja organisasi, khususnya BDK Semarang yang dinamis, kondusif dan professional sehingga dapat digunakan sebagai percontohan untuk peserta diklat kearsipan. Ruang penyimpanan arsip in aktif di record center terlalu kecil, sehingga banyak arsip keuangan yang belum dapat tertampung dan tertata.

\section{DAFTAR PUSTAKA}

Arsip Nasional Republik Indonesia. (1999). Modul manajemen arsip dinamis (Edisi Pertama). Jakarta: ANRI.

Ayu, G., \& Windarti, O. (2013). Penanganan Arsip Pada Bagian Umum Dan Akuntansi Pt . Bank Sumsel Palembang. 3(1), 1-21.

Azmi. (2016). Signifikansi Empat Instrumen Pokok Pengelolaan Arsip Dinamis. Jurnal Kearsipan, Volume 11, hal $15-38$.

Creswell, J. W. (2010). Research Design Pendekatan Kualitatif, Kuantitatif, dan Mixed Edisi Ke-3. Yogyakarta: Pustaka Pelajar.

Fitri dan Marlini. (2013). Penyusutan Dan Nilai Guna Arsip Di Umit Kearsipan Dinas Prasarana Jalan, Tata Ruang Dan pemukiman Provinsi Sumatera Barat. Jurnal Ilmu Informasi Perpustakaan Dan Kearsipan, Vol. 2(No. 1).

KMA. KMA No. 44 Tahun 2010 tentang Pedoman Pentaan Kearsipan di Lingkungan Kementerian Agama., (2010). 
Rachmaji. (2016). Peran Akuisisi Arsip Statis BUMN Terhadap Khazanah Arsip Statis BUMN di Indonesia. Jurnal Kearsipan, Volume 11, 1-14.

Sanora, N. A. (2016). Pengelolaan Arsip Pada Bagian Tata Usaha Biro Umum Kantor Gubernur Provinsi Kalimantan Timur. Universitas Mulawarman, (2), 4042-4056. Retrieved from http://ejournal.an.fisip-unmul.ac.id/site/wp-content/uploads/2016/06/Jurnal (06-16-16-04-4838).pdf

Sudjono. dkk. (2007). Penilaian dan Penyusutan Arsip. Jakarta: Universitas Terbuka.

Suraja. (2006). Manajemen Kearsipan. Malang: Dioma.

Sutirman, S. (2019). Urgensi Manajemen Arsip Elektronik. Efisiensi - Kajian Ilmu Administrasi, 13(1). https://doi.org/10.21831/efisiensi.v13i1.7861

UU No. 49 Tahun 2009. UU No. 49 Tahun 2009 tentang Kearsipan.

\section{UCAPAN TERIMA KASIH}

Artikel ini merupakan hasil dari penelitian yang telah dilakukan. Penulisan artikel ini tidak akan pernah terwujud tanpa bantuan dari berbagai pihak. Ucapan terima kasih kepada pihak-pihak yang telah berkontribusi pada semua proses pelaksanaan penelitian dan penerbitan artikel ini.

\section{PROFIL PENULIS}

Riskha Nur Fitriyah, S.Si, M.Pd adalah widyaiswara pada Balai Diklat Keagamaan Semarang, yang sebelumnya memiliki pengalaman menjadi pengelola arsip selama 8 tahun. 